\title{
Development of Instructional Design ICARE Assisted Learning Management System to Enhance the Learning Process
}

\author{
Wikan Budi Utami \\ University of Pancasakti Tegal, Indonesia \\ wikansatria@upstegal.ac.id.
}

\author{
Fikri Aulia \\ University of Pancasakti Tegal, Indonesia \\ fikri_aulia@upstegal.ac.id
}

\author{
M. Arif Budiman S \\ University of Pancasakti Tegal, Indonesia \\ arifups88@gmail.com
}

\begin{abstract}
Learning is a process of education conducted by the teacher to the learner, the learning will be more effective when utilizing media. The development of information and communication technologies have an important role in learning. In addition to media, instructional design is also influential in the learning process. In this study, researchers are interested in researching the development of ICT-assisted with learning design to improve the effectiveness of learning. This research aims to find hipotetik model of instructional design development ICARE assisted learning management system to improve the learning process, in addition to knowing their effectiveness. This type of research is research and development. Defined by the Borg and Gall (2003), that educational research and development is a process used to develop and validate educational products. Further they also suggested 10 measures of research and development, which can be simplified into the following five main steps: (1) conduct an analysis of the product to be developed; (2) develop the initial product; (3) expert validation and revision; (4) small scale field trial and revision products; and (5) large scale field tests and the final product. Researchers recommend that: (1) the application of instructional design ICARE-assisted Learning Management System should need to be developed to became a blended learning are more effective, and (2) the findings in this research so that it can be used more broadly.
\end{abstract}

Keywords: instructional design ICARE, learning management system, learning process

\section{INTRODUCTION}

Learning with instructional media will certainly have a positive impact on learning outcomes. As suggested by edgar dale in a cone of experience. Learning will be more effective if learning can experience a concrete learning process. One alternative that is expected to be able to answer the demands as well as accommodate the needs of learning effectiveness is the design of learning ICARE (Introduce, Connect, Apply, Reflect and Extend). Referring to the opinion of Hoffman and Ritchie [3], ICARE is a model of a learning system that begins with a practicum learning design used for online learning [4].

In the process of e-Learning who needs a Learning Management System (LMS), which serves to regulate the management of learning in the e-Learning model. LMS is also known as CMS (Course Management System), generally built web-based CMS, which will run on a web server and can be accessed by participants through a web browser (web client). Servers are usually placed in universities or other institutions, which can be accessed from anywhere by its participants, by utilizing an internet connection.

CMS basically provides a tool for instructors, educators or educators to create educational websites and manage access controls, so that only registered participants can access and view them. In addition to providing control, the CMS also provides a variety of tools that make learning more effective and efficient, such as providing services to facilitate uploading and sharing of learning materials, online discussions, chats, quiz reports, surveys, and reports.

The researcher develops the concept of ICARE Learning Design which is integrated with LMS. The problem to be answered in this research is how the implementation and effectiveness of instructional design of ICARE assisted Learning Managament System on improving the effectiveness of learning on the subject of numerical method on Mathematics Education students at University of Pancasakti Tegal?

\section{METHODS}

There are several steps of mechanism in designing LMS Application in this research. The LMS used in this study is moodle. This process starts from making Software Requirement Specification (SRS), making of application, making of system policy, socialization of E-Learning system, monitoring and Evaluation. SRS is designed based on system requirement analysis. SRS is a preliminary information about the steps of LMS system development, such as web structure, infrastructure needs, and domain / hosting. SRS is presented coherently in a book that guides the process of designing an application or an LMS. SRS also features flowchart, Flowchart is a picture or chart showing the sequence and relationship between process and its instructions. This picture is represented by a symbol. Thus each symbol describes a particular process.

That from the analysis done there are some things that become problems in conventional learning process, that is: (1) communication between students and lecturers who are not always fluent result in lack of time to discuss between lecturers and students; (2) lack of interaction that allows students to be more kreaktif and active in the learning process so that needed media who can simplify the process of this interaction; and (3) lack of references and references used so that 
generally $\mathrm{h}$ students receive materials presented lecturers in the classroom.

From the analysis of the problem then identified the objects that play a role in the system and to further be developed and more detailed in the results of the analysis. In this stage used the use case diagram to describe the functionality of the system from the perspective of the user so that it can be known clearly the scope of the system, the actors who play a role in the system, as well as the interaction between actors with the system. Based on the analysis there are some functionalities that must be available in the system that is the ease of the students to obtain information related to the courses that are taken either in the form of course descriptions, references used by lecturers in teaching as well as the possibility of students to download the material given by lecturers in the class so that it is possible for students who do not attend a meeting can still follow the material given in addition also to make it easier for lecturers and students in the process of data exchange.

The process of making the application in this study, researchers integrate LMS with the steps of ICARE design learning. Making the application done by the programmer. The programmer has full access in running the LMS app. ICARE as a learning design proceeds from the planning, implementation, to evaluation stage. ICARE stands for introduction, connection, application, reflection, and extend, which refers to the stages of the learning process. ICARE has the following characteristics: (1) based on student needs based; (2) planned and implemented with the spirit of contextual learning; (3) engage student with active learning; (4) provide enrinchment activities and fruitful reflection; and (5) internal school condition (teachers competency, school facilities, school comittes, and parrents). In making the application, the researcher has conducted a content test to ensure that the application is feasible to use [1]. Content testing involves experts in the field of e-learning, experts in course materials and students as users. The tested content gets some repair notes that are further improved so that the application is ready for use.

The system policy serves to inform the policy stakeholders at the institution so that the system designed by the researcher can be accommodated and harmonized with the system existing in the institution. This policy is made in order to avoid problems with the existing system. The system socialization stage is introducing LMS system that has been designed to users such as lecturers and students. This is done so that users can give a good response in its implementation.

\section{RESULTS AND DISCUSSION}

The ICARE learning design is basically inseparable from the improvement of the learning process section as implicit in the ICARE acronym itself. The stages in question are summarized below. Introduction. At this section of the learning experience, the lecturer instills an understanding of the content of the lectures to the students. This section should contain an explanation of the purpose of the course and what will be achieved or the results during the course. Introduction should be short and simple.

Connection. This section of learning process need for competency developed based on previous competencies. Therefore, all good learning experiences need to start from what is already known, can be done by students, and develop it. The lecturer attempts to connect new teaching materials to something already familiar to the students from previous learning or experience. Lecturers can do this by holding simple brainstorming exercises to understand what the students already know, by asking them to tell what they remember from previous lectures, or by developing an activity that the students themselves can undertake. After that, the lecturer can connect students with new information. This can be done through simple presentations or explanations.

Application. This section is the most important of lectures. Once students have acquired new information or skills through the connection stage, they need to be given the opportunity to practice and apply the knowledge and skills. The application sections should last the longest from lectures where students work alone, not with lecturers, in pairs or in groups to complete real activities or solve real problems using new information and skills they have acquired.

Reflection. This section is a summary of the learning process, while students have the opportunity to reflect on what they have learned. The task of the lecturer is to assess the extent to which the success of learning. Reflection or summary activities can involve group discussions where the lecturer asks students to make presentations or explain what they have learned. They can also perform independent writing activities where students write a summary of the learning outcomes. This reflection can also be a short quiz in which the lecturer asks questions based on lecture content. An important point to remember in reflection is that lecturers need to provide opportunities for students to express what they have learned.

Extend. This section has been completed, it does not mean that all the students who have studied can automatically use what they have learned. The extension section activity is an activity where the lecturer provides activities that students can do after the lesson / session ends to strengthen and expand the learning. Extension activities are usually called homework. Extension activities may include the provision of additional reading materials, research assignments or exercises.

ICARE learning design developed in this study is a learning design that is integrated with the Learning Managament System which aims to improve the effectiveness of learning in the course of Numerical Methods in Mathematics Education Program of Pancasakti University Tegal. The process is carried out through the following two stages.

The activities that researchers undertake prior to the application of the ICARE learning design are the orientation and preparation of the design of the design. The orientation of ICARE learning design is done by introducing it to the lecturer through discussion. From the discussion is expected to form a common 
understanding between the author and lecturer as research collaborators, especially about learning ICARE and drafting design that will be applied. Lecturers acknowledge that they have often heard and want to apply the design. Nevertheless, they have not applied them fully because of their limited knowledge and abilities.

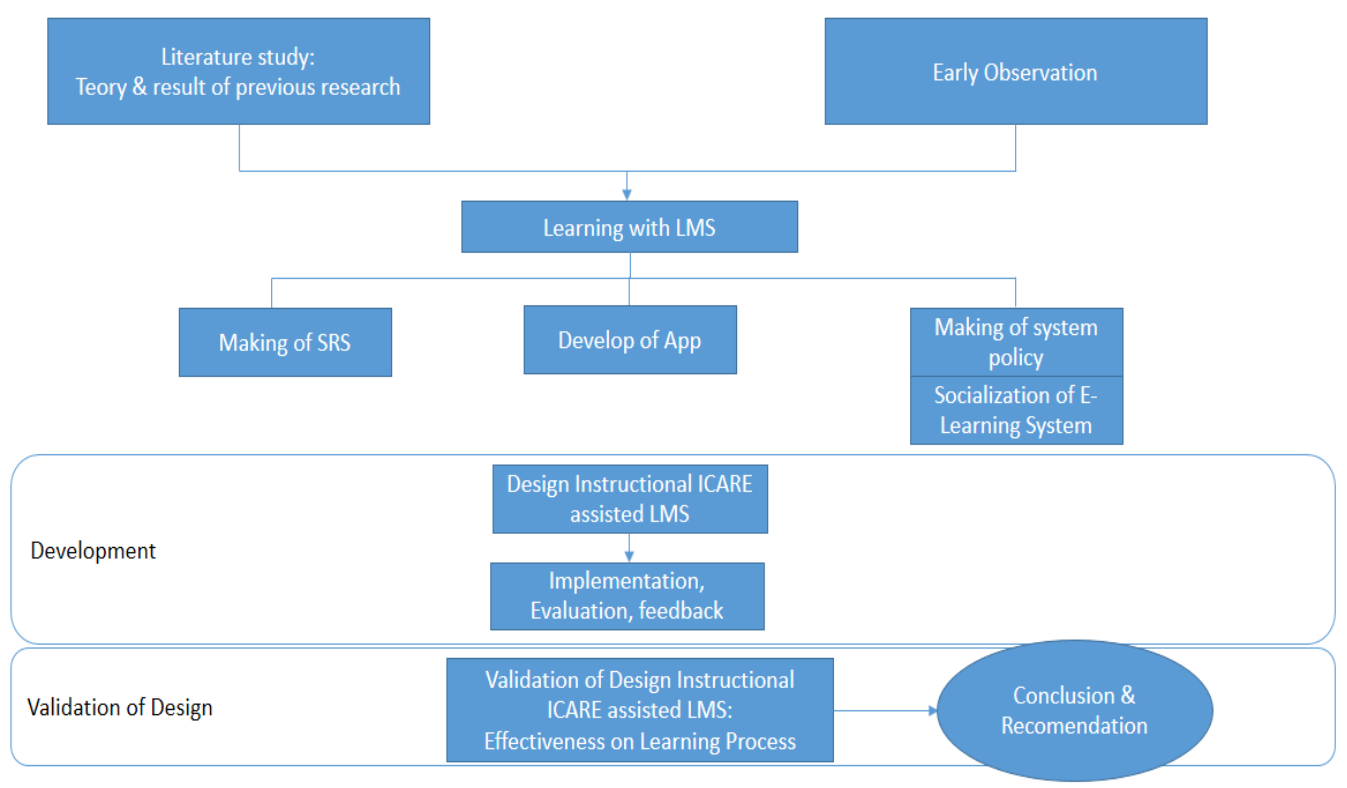

Figure 1

The Development of Instructional Design ICARE Assisted LMS

The design of ICARE learning design is done collaboratively by the writer with the lecturer. The design of the design is related to the semester implementation plan (RPS). The ICARE learning component developed outline includes objectives, materials, activities, media, and learning evaluations. Learning objectives are arranged to refer to the learning objectives based on the applicable curriculum. The development of instructional objectives is directed toward the effectiveness of learning [2].

The material in the ICARE learning design is determined based on the subject matter to be studied. The subject is sourced from the numerical standard competency course standard as stated in the RPS. For the purpose of this research is determined semester lecture material VI, that is solution of linear equation. The learning activities developed in the ICARE learning design consist of five stages. Each stage is manifested in several lecturer and student activities. The media / tools and learning resources used in the ICARE design study in this study include: (1) the source book (student handbook) as a reference for understanding learned theories and practices; and (2) LMS Application.

The evaluation used includes evaluation of the process and evaluation of results. Process evaluation is carried out using instruments in the form of observation guidelines during the learning activities take place. Evaluation of learning outcomes done through prates and pascates using objective test forms in writing. Evaluations are directed at assessing the effectiveness of learning. Assessment indicators include material knowledge, understanding, application, analysis, and applying concepts.
The design of the ICARE instructional design and its entire device is validated first through expert judgment by both IT experts and content specialists. The product of this stage activity is the implementation plan of learning design ICARE assisted LMS. The learning implementation phase of ICARE design is done by experimental approach. At this stage, it is studied about the implementation of ICARE instructional design that was developed, then made improvements based on the results of the implementation, discussion, and suggestions from lecturers.

Implementation of learning design ICARE design was treated in the experimental group, for the sample is students of Mathematics Study Program semester VI consisting of 3 classes with the amount of each of 27 students, 28 students, and 27 students. Before implementing the ICARE learning design, each class is given a preview to ensure the equivalence of initial knowledge. Against the prates of each class then tested the homogenity with the following results.

Based on the results of the analysis, with Ho: $\sigma_{1}^{2}=\sigma_{2}^{2}$ (same variant $=$ both homogeneous groups); and H1: $\sigma_{1}^{2} \neq \sigma_{2}^{2}$ (variant is not equal = both groups are not homogeneous), found $\mathrm{sig}=0.013=13 \%>5 \%$ so $\mathrm{Ho}$ is accepted. This means that each class is homogeneous (has the same variant). Therefore, each class can be treated in accordance with the planned, learning design ICARE assisted LMS for the experimental group. The design and implementation of ICARE for the experimental class is summarized below. 
Table 1

The Homogenity of Sample

ANOVA
\begin{tabular}{|l|r|r|r|r|r|}
\hline Result & \multicolumn{1}{|c|}{ Sum of Squares } & df & Mean Square & F & Sig. \\
\hline Between Groups & 2030.702 & 2 & 1015.351 & 4.638 & \\
\hline Within Groups & 16639.070 & 76 & 218.935 & & \\
\hline Total & 18669.772 & 78 & & & \\
\hline
\end{tabular}

The result of observation during the first experiment of applying the learning design ICARE shows that the learning process is quite good, in the sense not dominated by the lecturer. In addition, the lecturer try to build an interactive atmosphere of dialogue with students. Another factor that leads to student difficulties is the presentation of less systematic pilots and less in line with the instructional material presented. In addition, the lecture material presented is not associated with real experience and its usefulness for student life.

Based on these facts, the writer along with the lecturer of the numerical method discuss and agree on the preconditions for the second experiment. The precondition is the need for the delivery of learning objectives and checking student entry behavior at the introducing stage, intensifying monitoring of student progress and progress during the learning process, and developing evaluation materials that focus on evaluating the effectiveness of learning with learning achievement indicators. Lecturers should also be more active in directing and guiding students in the process of discussion so that students really can absorb the core of the material discussed through discussion activities.

In relation to the preconditions, the authors revised the ICARE learning design especially to proportionalize the planned time allocation so that all materials could be delivered in accordance with the time allocation. In practice, the lecturer should utilize the time as efficiently as possible to prevent repetitive discussion of the material. The design learning ICARE assisted LMS applied in this second experiment is expected to be better than that applied in the first experiment. Better in the sense that this design becomes a guide to the learning process that accommodates the achievement of competence and learning objectives, ensures the learning process that activates the students, and position the lecturer as the student learning facilitator.

Based on the observation of the process and the second experiment result of the application of the ICARE learning design, the condition of the learning process has shown better student and lecturer activity. All students look more focused on the learning materials presented. The learning process is almost completely centered on the students. Lecturers were seen placing their position as mentors and facilitators in learning.

The process of developing conceptual understanding takes place at the connection stage, ie the stage of the delivery of the material thoroughly. At this stage students seem to be relatively quick to learn the lectures of numerical methods. The use of LMS by lecturers, making the communication process at connection stage more attractive. Students are also more active in questioning the material of numerical methods, especially concerning solutions of nonlinear equations that they think are confusing.

Table 2

The Result of Efectiveness

\begin{tabular}{|c|c|c|c|c|}
\hline \multicolumn{5}{|c|}{ Paired Samples Correlations } \\
\hline & & $\mathrm{N}$ & Correlation & Sig. \\
\hline Pair 1 & pretest \& posttest & 79 & .505 & .000 \\
\hline
\end{tabular}

Paired Samples Test

\begin{tabular}{|c|c|c|c|c|c|c|c|c|c|}
\hline & \multirow{2}{*}{\multicolumn{5}{|c|}{ Paired Differences }} & \multirow[b]{4}{*}{$\mathrm{t}$} & \multirow[b]{4}{*}{ df } & \multirow{4}{*}{$\begin{array}{l}\text { Sig. }(2- \\
\text { tailed) }\end{array}$} \\
\hline & & & & & & & & & \\
\hline & & \multirow[b]{2}{*}{ Mean } & \multirow[b]{2}{*}{ Std. Deviation } & \multirow{2}{*}{$\begin{array}{l}\text { Std. Error } \\
\text { Mean }\end{array}$} & \multicolumn{2}{|c|}{$\begin{array}{c}95 \% \text { Confidence Interval of } \\
\text { the Difference }\end{array}$} & & & \\
\hline & & & & & Lower & Upper & & & \\
\hline Pair 1 & pretest - posttest & -4.65823 & 13.83222 & 1.55625 & -7.75648 & -1.55998 & -2.993 & 78 & .00 \\
\hline
\end{tabular}

At thereflect and extend stage students are asked to discuss by utilizing LMS outside the lecture. Lecturers provide time to discuss in solving problems in lecturing process through LMS. In the result of processing using SPSS showed that the level of significance 0.505 which means the design of LARB assisted ICARE learning has a positive contribution in improving the effectiveness of the learning process in the course of numerical methods by $50.5 \%$. There are factors that influence the effectiveness of the learning process by $49.5 \%$.

\section{CONCLUSION}

Learning Management System's ICARE Learning Design System is effective in improving the effectiveness of learning. Lecturers and Students are helped by the LMS so that the material delivery process is more optimal. A good internet connection is required in using an LMS. Learning designs assisted LMS still need to be developed in order to create more effective blended learning. 


\section{REFERENCES}

[1] Borg, W, \& Gall. 2003. Educational Research: An Introduction. New York: Longman.

[2] Budiman, M. A., and Hasan, U. I. A. 2017. Keefektifan Layanan Penguasaan Konten dengan Media Audiovisual dalam Pemantapan Perencanaan Karier Peserta Didik Kelas X Multimedia SMK N 1 Slawi. Cakrawala Jurnal Pendidikan, 11(2), 25-31.

[3] Hoffman, R., \& Ritchie, D. 1998. Teaching and Learning Online: Tools, Templates and Training. In SITE Annual 1998, CD-ROM, Charlottesville, VA: Association for the Advancement of Computing in Education. Retrieved December 19, 2016, from http://www.cssjournal.com/hoffman.html.

[4] Isnani, Wikan B. U., Amalia, S. R., and Aulia, F. The Use of Ethnomathematics Project Based Learning Model to Improve Capabilities Mastery Concept Applicable and Process Skills. International Conference on Research, Implementation and Education of Mathematics and Science (4 ${ }^{\text {th }}$ ICRIEMS), Yogyakarta, State University of Yogyakarta, 14-16 May. 